Smitherman, Geneva (2004). Language and African Americans: Movin on up a lil higher. Journal of English Linguistics 32(3):186-96.

(Received 08 November 2017)

Address for correspondence:

Mary Bucholtz

Department of Linguistics

3432 South Hall

University of California, Santa Barbara

Santa Barbara, CA 93106-3100, USA

bucholtz@ucsb.edu

\title{
Error correction and social transformation in Creole studies and among Creole speakers: The case of Haiti
}

\author{
M I C H E L D e G R A F F \\ Massachusetts Institute of Technology, USA
}

FROM 'ERROR CORRECTION' TO 'CR ITICA L

R E F L E X I V I T Y,

Mark Lewis asks that socially engaged linguists go beyond Labov's (1982) principle of error correction (PEC) so that we can enlist critical race theory (CRT) to address 'more difficult and fundamental questions of the sociohistorical conditions of a representation of language, challenging its premises and showing its connections to racial, economic, or other forms of violence' (Lewis, this issue, p. 341). The ultimate goal is the actual TRANSFORMATION of the socioeconomic structures responsible for structural violence against speakers of stigmatized languages.

Though heartening, the article fails to acknowledge a long tradition of scholar activists, including Frantz Fanon, Paulo Freire, Pierre Bourdieu, and Michel Foucault, whose work has directly aimed toward 'actual transformation' through understanding of 'power/knowledge' systems (à la Foucault) that often include race, class, ethnicity, gender, sexuality, and other variables underlying various sorts of domination.

Lewis' call for 'critical reflexivity' implicitly echoes my own plea, in this very journal, that 'reflexive creolistics' can help transform the material conditions of Creole speakers: 
(i) through progress in our current knowledge about the history and structures of Creole languages and about the genealogy and sociology of Creole studies; and (ii) eventually through application of our improved knowledge to new and truly progressive paradigms in research, in education reform and language policy (DeGraff 2005:80).

My current work, as part of the MIT-Haiti Initiative for opening up quality education to all in Haiti, ${ }^{1}$ has simultaneously targeted both individual beliefs based on misrepresentations of Creole languages and pedagogical mispractices, with deeply entrenched sociohistorical bases, around the (mis)use of language in education. It is such misuse of language, among other practices, that often result in 'racial, economic, or other forms of violence'.

\section{FROM HAITI TO MIT TO MIT-HAITI}

In Haiti, through the use of French as primary language in schools and other formal domains, those who speak Kreyòl only (i.e. the vast majority of eleven million Haitians) have been excluded from access to quality education and upward mobility. This 'linguistic apartheid' is often clothed in a local analogue of the 'verbal deprivation' theory whereby Kreyòl is misperceived or misrepresented as a structurally 'impoverished' or 'broken' or otherwise exceptionally lesser language that cannot express the complex concepts that are needed for formal administration and adequate education.

In effect, then, beliefs and attitudes toward Kreyòl in Haiti are reminiscent of those about African-American English (AAE) in the US, even though Kreyòl in Haiti is spoken by all, while AAE is spoken by a minority of the US population. While AAE is often considered a proxy for race, Kreyòl in Haiti, especially the varieties spoken by monolingual Kreyòl speakers, is considered a proxy for class. As such, PEC-based efforts and limitations thereof in the Kreyòl context may provide some useful control (and perhaps recommendations) for their counterparts in the AAE context, especially keeping in mind that Kreyòl, unlike AAE, is already recognized as a co-'official' and 'national' language according to Haiti's 1987 Constitution.

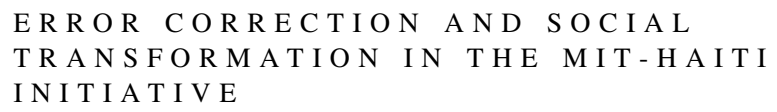

This Initiative has moved well beyond error correction (i.e. beyond simple 'public engagement') to the extent that we are demystifying 'marginalizing representations' of Kreyòl and concretely addressing the 'material conditions and social positions [that are] supported by these [marginalizing] representations' (Lewis, this issue, p. 325). So, well in advance of Lewis' analysis, we have already placed IDEOLOGIES and related institutional practices at the center of our efforts toward social change. In Haiti too, these ideologies are made concrete via representations 'that are material, 
perceivable, and often embedded in institutionalized practices such as, in the case of marginalized language practices in schools, curricula or teacher training materials' (Lewis, this issue, pp. 328-329). In this particular case, the error has consisted, and often sTiLl consists, in using French to teach, examine, govern, and judge Haitians who mostly speak Kreyòl only.

In Haiti, like in the Ann Arbor case recapitulated by Lewis, 'error correction fails to achieve its goals' (Lewis, this issue, p. 327). Lewis' statement that '[mis]representations of language [are] always linked to the interests of differently positioned social actors and often embedded within institutionalized practices' (Lewis, this issue, p. 328) echoes both Foucault's 'power/knowledge' framework (1980) and Myers-Scotton's concept of 'élite closure' (1993). The latter is 'a type of social mobilization strategy by which those persons in power establish or maintain their powers and privileges via linguistic choices' (Myer-Scotton 1993:149). In Haiti, French is a means of control and exclusion by a minority of French-Kreyòl bilinguals, to the detriment of the Kreyòl-speaking monolingual majority. What's most needed, over and beyond 'dissemination of knowledge', are concrete ACTIONS that can change attitudes and practice, and that can include the use of Kreyòl in education and other avenues where economic and political power and social prestige are created and transmitted. These actions should be designed toward breaking 'élite closure' (à la Myers-Scotton), creating new 'régimes of truth' (à la Foucault), and opening up quality education and other socioeconomic opportunities for those who have been excluded.

It is thus that the MIT-Haiti Initiative's engagement in Haiti is all about social change. As we engage in situ with Haitian educators and as we document the use of Kreyòl for improving education (Dizikes 2015; DeGraff 2017b; DeGraff \& Stump 2018), we also share our results among the general public via various sorts of outreach, including social media, thus reaching to stakeholders that have the most to gain from the paradigm shift that is being ushered, namely teachers, students, and their parents. Our objective, indeed, is to change the material conditions of those that are most affected by the exclusion of Kreyòl in Haitian classrooms.

\section{KREY ÒL PROVERBS AS RESOURCE FOR ERROR CORRECTION AND SOCIAL CHANGE}

Kreyòl proverbs suggest that Kreyòl speakers already understand the role of ideologies in creating and maintaining hierarchies of power. Consider proverbs like Pale franse pa vle di lespri 'That you speak French does not mean that you're intelligent' and Kreyòl se lang rasin; franse se lang achte 'Kreyòl is our ancestral language whereas French is a language that you buy'. They suggest a MATERIALIST perspective on the Kreyòl vs. French divide in Haiti- 'materialist' in Lewis' sense, that is, as 'a means by which society allocates privilege and status' via hierarchies that 
'determine who gets tangible benefits' (Delgado \& Stefancic 2001:17, quoted in Lewis, this issue, p. 329).

These hierarchies are not (only) racial, but they are also delineated by levels of mastery of French. In Haiti, the phrase Franse mawon 'Brown French' refers to varieties of French whose linguistic structures reveal a noticeable Kreyòl influence. The discursive link between 'incorrect French' and 'Brown French' ('brown' as in 'brown skin' or as in marronage —-'escape from slavery') reveals connections among race, slavery, colonization, language, and class. It thus seems that we Haitians are, not 'idealist', but 'materialist' and 'race-critical theorists' in our understanding of the material privileges afforded by French-based 'élite closure' in Haiti. We certainly understand that the distribution of these privileges is rooted in Haiti's colonial history with its brutal race- and class-based hierarchies.

I N D I V I D U A B E L I E F , L A N G U A G E I D E O L O G IES, A N D I S T I T U T I O A L T R A N F O R A T I O N G O HAND IN HAND-OR LET'S NOT THROW OUT THE B A B Y W T T THE B A TH W A T E R

The MIT-Haiti Initiative's long-term objectives are a pipe dream if the state and the business sectors continue to discriminate against Kreyòl-only speakers in spite of official agreements to promote Kreyòl. Meanwhile the Initiative is helping create the foundations for a more level playing field where Kreyòl-speaking communities can eventually have access to quality education. It is the increased possibility for such access that addresses, and requires, the need for deep transformation at the political and institutional level as well — very much in the manner advocated by Lewis and many others before him, going all the way back to Marx (Engels 1886). These political and institutional transformations go hand in hand with changes in attitudes at the individual level. Indeed once teachers and students understand the benefits of teaching and learning in their native language and once they have experienced the power of the native language as an indispensable tool toward equal access to quality education, they are likely to become, as the Haitian proverb would have it, like zonbi ki goute sèl (i.e. like 'zombies who have tasted salt' - and who have recovered their full agency as socially conscious human beings). As such, they will be more disposed to work toward institutional change in favor of education in the mother tongue.

In effect, then, these two levels of change complement each other: (i) the individual changes of beliefs and attitudes vis-à-vis Kreyòl for education and administration (i.e. changes related to individual-level mental states), and (ii) the institutional transformation that will cement the use of Kreyòl in this formal capacity.

In fact, one may also claim that attitude changes (via 'error correction' about Creole languages) may well be at least as important among professional linguists as they are among the general public, considering that it is the job of linguists to analyze, document and represent language accurately. Yet, it is also linguists 
(fortunately, some, not all, linguists) who 'relegate Creole languages to some non'regular', non-'normal', and/or 'deficient' typology with properties that seem unexpected from any natural language. Such stereotypes actually reinforce the status of Creoles as languages that are unfit for education and for general use in Creolophone communities (or any human society whatsoever)' (DeGraff 2001:104). So my work already documents 'how academic scholarship has produced and continues to produce knowledge about language in ways linked to existing systems of marginalization' (cf. Lewis, this issue, p. 340).

My 2005 article in Language in Society aimed at demystifying 'existing systems of marginalization' within Creole studies. In fact, the rationale for my attempts at error correction with respect to what I have called Creole exceptionalism is straightforwardly rooted in my understanding of the very emergence of these misrepresentations of Creole languages as 'a rather banal consequence of European imperialism in Africa and the Americas' (DeGraff 2005:569), that is, a 'rather banal' correlate of the racism that was part and parcel of such imperialism (see e.g. Trouillot 1995, DeGraff 2005). In my papers on Creole exceptionalism, I've enlisted analyses by Frantz Fanon (1952, 1959, 1961), Pierre Bourdieu (1982; see also Bourdieu \& Wacquant 1992), Michel Foucault (1980), and so on, in considering such 'errors' a straightforward consequence of the mutually reinforcing interaction between systems of power and systems of knowledge. These analyses, with implicit foundations in critical race theory, are, by necessity, 'materialist' as they locate the origins of these 'errors' squarely in the functioning of institutions such as schools, universities, and state institutions.

Thus, my own understanding, for quite some time now, is that the dogmas of Creole exceptionalism and the corollary exclusion of Creole languages in formal institutions, alongside many other 'errors' to be corrected about Black and Brown people around the globe, are consequences of geopolitical and race- and class-based power grabs. It is this understanding that has led me to launch the MIT-Haiti Initiative. Now I am collaborating with the Boston Public Schools as we correct these institutional mechanisms whereby speakers of Creole and of other non-English languages are viewed as deficient. One such effort is the recent launching, in 2017-2018, of a Kreyòl/English Dual Language Program in a Boston neighborhood with a large population of Haitian immigrants - many of whom have, in the past, been viewed as deficits instead of assets, because of their native languages. In these programs, immigrants' home languages such as Kreyòl are viewed as assets for enhancing these children's academic success (García Mathewson 2017; Vaznis 2017).

All of this constitutes a tall order. But social change around the (mis)use of Creole languages is in progress in Haiti and beyond, at both the individual and the institutional levels, toward equal opportunity in academic and socioeconomic terms (Dizikes 2015; DeGraff 2015a,b, 2017a,b; DeGraff \& Stump 2018). More generally, what Lewis exhorts us to do for social change around AAE speakers is already happening in the work of Smitherman (2000), Labov (1982), Devonish 
(2007), Rickford \& King (2016), Baugh (2018), Charity Hudley \& Mallinson (2014), and others.

To end, I quote my late mentor Ken Hale who understood long ago that one criterion for the success of linguistics is its concrete influence toward social change among the communities we study:

In carrying out field research, linguists are inevitably responsible to the larger human community which its results could affect... What matters is eventual success, and that will be measured by the extent to which work on the language is integrated in a meaningful way into the life of the community of people who speak it. (Hale 2001:76, 100)

\section{N O T E}

${ }^{1}$ https://www.nsf.gov/awardsearch/showAward?AWD_ID=1248066

http://haiti.mit.edu,

http://linguistics.mit.edu/linguistics_haiti/

https://www.facebook.com/mithaiti

\section{R E F E R E N C E S}

Baugh, John (2018). Linguistics in pursuit of justice: Colorblind ambition. Cambridge: Cambridge University Press.

Bourdieu, Pierre (1982). Ce que parler veut dire: L'économie des échanges linguistiques. Paris: Fayard [English edition, Language and symbolic power, ed. \& trans. by Gino Raymond \& Matthew Adamson. Cambridge, MA: Harvard University Press, 2001].

— \& Loïs Wacquant (1992). An invitation to reflexive sociology. Chicago: University of Chicago Press.

Charity Hudley, Anne \& Christine Mallinson (2014). We do language: English language variation in the secondary English classroom. New York: Teachers College Press.

DeGraff, Michel (2001). Morphology in Creole genesis: Linguistics and ideology. In Michael Kenstowicz (ed.), Ken Hale: A life in language, 53-121. Cambridge, MA: MIT Press.

(2005). Linguists' most dangerous myth: The fallacy of Creole exceptionalism. Language in Society 34(4):533-91.

(2015a). France's misconceived 'Marshall Plan' for Haiti. Le Monde Diplomatique, May 26, 2015. Online: http://mondediplo.com/blogs/france-s-misconceived-marshall-plan-for-haiti.

(2015b). Kreyol-based and technology-enhanced learning of reading, writing, math, and science in Haiti: Project outcomes report. National Science Foundation. Online: http://1.usa.gov/ 1JUdvpt.

(2017a). Haiti's 'linguistic apartheid' violates children's rights and hampers development. openDemocracy. Online: https://www.opendemocracy.net/openglobalrights/michel-degraff/haiti-s-linguistic-apartheid-violates-children-s-rights-and-hampers-.

(2017b). Mother tongue books in Haiti: The power of Kreyòl in learning to read and in reading to learn. Prospects. Online: http://rdcu.be/qm1X.

_ \& Glenda S. Stump (2018). Kreyòl, pedagogy, and technology for opening up quality education in Haiti: Changes in teachers' meta-linguistic attitudes as first steps in a paradigm shift. Language, to appear.

Delgado, Richard, \& Jean Stefancic (2001). Critical race theory: An introduction. New York: New York University Press.

Devonish, Hubert (2007). Language and liberation: Creole language politics in the Caribbean. Kingston: Arawak. 


\section{MICHEL DeGRAFF}

Dizikes, Peter (2015). Three questions: Michel DeGraff on Haiti's new policy for teaching in Kreyòl. MIT News, July 20, 2015. Online: http://newsoffice.mit.edu/2015/3-questions-michel-degraff-haititeaching-kreyol-0720.

Engels, Friedrich (1886). Ludwig Feuerbach und der Ausgang der klassischen deutschen Philosophie. Stuttgart: Verlag [English edition, Ludwig Feuerbach and the end of classical German philosophy. Progress Published, 1946. Online: https://www.marxists.org/archive/marx/works/1886/ludwigfeuerbach/index.htm].

Fanon, Frantz (1952). Peau noire, masques blancs. Paris: Seuil [English edition, Black skin, white masks, trans. by Charles Lam Markmann. New York: Grove Weidenfeld, 1991].

(1959). An cinq de la révolution algérienne. Paris: François Maspero [English edition, Studies in a dying colonialism, trans. by Haakon Chevalier. London: Earthscan, 1991].

(1961). Les damnés de la terre. Paris: François Maspero [English edition, The wretched of the Earth, trans. by Constance Farrington. New York: Grove Weidenfeld, 1989].

Foucault, Michel (1980). Power/knowledge: Selected interviews and other writings 1972-1977, ed. by Colin Gordon, trans. by Colin Gordon, Leo Marshall, John Mepham, \& Kate Soper. New York: Pantheon.

García Mathewson, Tara (2017). How discriminination nearly stalled a dual-language program. The Atlantic. April 7, 2017. Online: https://www.theatlantic.com/education/archive/2017/04/how-discrimination-nearly-prevented-a-dual-language-program-in-boston/522174/.

Hale, Ken (2001). Ulwa (Southern Sumu): The beginnings of a language research project. In Paul Newman \& Martha Ratliff (eds.), Linguistic fieldwork, 76-101. Cambridge: Cambridge University Press.

Labov, William (1982). Objectivity and commitment in linguistic science: The case of the Black English trial in Ann Arbor. Language in Society 11(2):165-201.

Myers-Scotton, Carol (1993). Elite closure as a powerful language strategy: The African case. International Journal of the Sociology of Language 103(1):149-64.

Rickford, John R., \& Sharese King (2016). Language and linguistics on trial: Hearing Rachel Jeantel and other vernacular speakers in the courtroom and beyond. Language 92(4):948-88.

Smitherman, Geneva (2000). Talkin that talk: Language, culture, and education in African America. New York: Routledge.

Trouillot, Michel Rolph (1995). Silencing the past: Power in the production of history. Boston, MA: Beacon Press.

Vaznis, James (2017). A Haitian Creole program arrives in Mattapan. Boston Globe. September 7, 2017. Online: http://www.bostonglobe.com/metro/2017/09/06/mattapan-haitian-creole-program-for-preschoolers/O6PydlII1WWoaOGdqlYYZJ/story.html.

(Received 04 February 2018)

Address for correspondence:

Michel DeGraff

MIT Linguistics \& Philosophy

32 Vassar Street

Cambridge, MA 02139, USA

degraff@MIT.EDU 